Kohl: a Journal for Body and Gender Research

Vol. 1, No. 2 (Winter 2015)

\title{
The Hystory of My Vagina: A Manifesto
}

Lady Gya 
Disclaimer: the author does not pretend to represent anyone but herself. None of the behaviors, reactions, and hystories ${ }^{1}$ should be understood as universal or essentialist truths. While many people with vaginas could relate to one or more parts of this manifesto, every story is about the author's vagina, and her vagina alone.

\section{My vagina is brown and hairy.}

It is not exactly brown; it is actually a fade shade of pink, and it flushes deeply to a vivid crimson when it is aroused. It is not particularly hairy either: it was hairy before my mother decided to eradicate my pubes with a laser weapon when I was 14.

The first time a woman touched my vagina, it was at a beauty center. She was wearing white medical gloves. She shaved my vagina before attacking its skin with painful bursts of laser light. The overwhelming smell of burnt hair that took over the room made me blush. The woman in white latex gloves whispered to me that my future husband might not like it completely hairless, that he might feel he is sleeping with a little girl. Despite her heterosexist assumptions, I owe her the thinned tuft of pubes that still ornaments the top of my vaginal lips.

\section{My vagina is politically brown and hairy.}

Because I am from a place where my vagina is imagined as an exotic delight. Because it is lusted after as are vast territories waiting to be conquered, saved, or liberated. Because it is queer, and it makes white saviors drool with the anticipation of victimizing it. Because I was told years ago that if I touched it, I could infect it with microbes. Because they said I could "hurt" myself and permanently "damage" it. Because it doesn't give a flying vaginal fart about dichotomies. Because it is perfectly fine as it is, unliberated and fondled. Because it is fighting its own fights with spatters of vaginal discharges and blood.

\section{My vagina bleeds.}

The first time it bled, I knew why - I had read all about it in a thick encyclopedia that smelled of old, yellowing paper. That day, I smelled of rusty metal and nutmeg. I ran to the living room and lowered my panties in front of my father and brother, revealing a dark red spot on the white fabric. "Look!" I said, with overjoyed squeals of excitement, "look! I got my period." They didn't say a word, but I remember the look on their face. I was

\footnotetext{
${ }^{1}$ Hystory stems from the matrilineal origin of telling stories about the vagina; they are traditionally passed on from womb to womb. Queer communities of brown women and transgendered individuals build on that notion by subverting the essentialism of the "womb" and occupying the public sphere. Hystory is the vagina's history as it transits from oral to written, from vertical modes of transmission to horizontal processes of sharing practices and stories.
} 
instructed not to leave any trace behind, to fold the tissues well after I wipe off my menstrual blood. As if to pretend my period did not exist.

My period is not dirty. It is fascinating and powerful. It marvels me with its ability to let go. This is also why it is painful sometimes, but it liquefies my body in heaves and sighs of release. I grew fond of the blackened membranes of congested tissues and vessels that occasionally escape my vagina with a "blob." I recollect them on a tissue to probe and poke them, or I curiously watch them as they battle the drain's metal bar to drown in the shower's pipes.

\section{My vagina has a memory.}

My mother used to marinate my vagina by making me sit in a basin of hot water spiked with toilet disinfectant. To keep it clean, she said. I silently itched for months. At the hospital, they inserted a raspy cotton swab in the folds of my vagina. I barely felt it inside me, but I cried soundlessly. My body reminds me of its hystory every couple of months. It greets me with thick, white discharges and infuriating itches that disturb my sleep.

My vagina likes natural remedies for its chronic yeast infection: a dab of yoghurt, a garlic clove, going commando. When doctors tried to treat it with strong antibiotics, the bacterial flora of my vagina groaned in protest, and my discomfort became more severe. Maybe it is because my mother does not remember that she repetitively soaked my genitals in cleaning products. I like to think that my vagina is ecofeminist and anticapitalist in that way. It hums its past in fluid colors and textures.

\section{My vagina grows sores.}

To this date, it only did once. I writhed with pain when pee came into contact with my burning vulva. For hours, I stared at my vagina's reflection in the small, rounded mirror. It stared back at me, grey and mousy and drooping. I searched between its folds for the clusters of sores, and I found them well-seated at its entrance. As I explained, spread-eagled in a gynecologist chair, the detailed evolution of my outbreak, the doctor interrupted me with an "it's herpes" verdict. He took a painful swab of the blisters, and it felt as if he was ripping my skin apart.

My feeling-highly-unattractive-self reached for support, which was plentiful and outpouring. Friends who went out of their way to share their own hystories with infections. Sisters who trivialized my "condition" over hot cocoa and warm hugs. Partners who reassured me with an "I love you, with or without herpes." They lifted me up enough to break my pattern of self-pity, and I felt compelled to take better care of my body, to treat it

with love and kindness. My test results came back negative, to my doctor's bewilderment. He had no definite answer for me, and his elucidation oscillated between a lab mistake and an allergy to some obscure medicine I had never taken. At that point, it did not matter to me whether I had herpes or not. I was too far gone into 
the path of self-care and acceptance. What I had learned from collective support resonated much deeper than the state of a viral load: the sores on my vagina healed the moment I embraced them.

\section{My vagina is not a hymen.}

It never cared about "preserving" one. I was not a virgin when I went for my first pap smears. My vagina was already enjoying fingers, tongues, and vibrators, and I did not feel I needed an "update" about the status of my hymen. The speculum excessively distorted my vagina, definitively dilating the thin membrane. I wiped the blood off my thighs with a shrug. My hymen "broke" - or rather, expanded - at the gynecologist. It was my own minute revolution against the myths and tales of self-respect and decency I was spoon-fed throughout my childhood.

My vagina sometimes bleeds with new lovers, as if growing accustomed to their touch, as if we are losing the virginity of the knowledge of each other's bodies.

\section{My vagina likes other brown vaginas.}

It likes to press and rub against them, only when they want that, too (it finds consent extremely sexy and unnegotiable). But it is crazy about one particular brown vagina. While it is not especially monogamous/amorous, it fell open in a wet, oblong "O" the moment our bodies touched. Far from reducing her to her sexual organs, her erotic power made me dizzy with the aftermath of political resistance. We are separated by impassable borders, but she still taught my vagina how to love in our mother tongue - though she used dammeh's instead of kasra's. I had touched and been touched in so many colonial languages, that abruptly coming face to face (or vagina to vagina) with my roots was uncanny. I was coming home. As our vaginas lay on top of each other, she rested her head on my chest and listened to the rhythm of my body. Arabic sounded different under my flesh, like a new methodology of being. Akh, my vagina can only ever love in Arabic.

\section{My vagina is wet.}

It drips with desire, it decants lust and emits aromas of arousal that titillate my nostrils through my pants. But sometimes, in the middle of sex, it suddenly dries up. It does not care that I am enjoying myself. My vagina whimsically demands attention. It values playfulness and hates mediocrity. It shies away from overstimulation, but it mouths its love story with a bottle of lubricant. I can almost hear it chuckle.

My vagina gets wet for the wrong reasons. When I am taking an exam. When I am in a meeting. When I am stressed. When I internalize my anger. In class. On the plane. In a family gathering. It irritably contracts, and 
I feel traces of fluid trickling down my vaginal lips. Years before, it used to mortify me. But my vagina conveys emotions and spits reactions, and I learned to shamelessly listen.

\section{My vagina orgasms.}

Mainly, my vagina has clitoral orgasms. It does not perceive vaginal orgasms as more "evolved." It is insolently non-hierarchal. My clitoris comes in waves of pleasure that shake my body and blur my vision. Sometimes, it orgasms so powerfully that I temporarily lose my hearing. As my body sighs, motionless, my vulva breathes in almost painful, numbing contractions that diffuse to the tips of my limbs. Other times, my clitoris is insatiable; it desperately swells and twitches in an attempt to reach for the fingers and tongues that pleasured it moments ago.

For a long time, I bore the guilt of not coming fast enough. But pleasure is a shapeshifter, and my vagina sulks when it is rushed. Whether alternately or simultaneously and in no particular order, it gets excited at the prospect of being teased, licked, sucked on, fingered, brought to the edge, then denied orgasm. It unapologetically enjoys consensual power play. My vagina knows how to relinquish power and reclaim it, ridding me of my insecurities in the process.

\section{My vagina loves fisting.}

Just when I thought I had tamed my sexual organ, it astounded me with its colossal power and strength. I watched as my vagina ravenously devoured the lubricated fingers of my partner, one after the other, sucking on them, luring them in. With no further ado, a wrist effortlessly disappeared inside it. My vagina hides a ring of fire, saturated by the gesticulating fingers that opened and closed inside its flesh.

When the fist abandoned my body, it left a gaping cavity behind. As the wings of expanded skin flapped against my labia, I inquisitively wondered whether my vagina had been dilated past the point of no return. I jokingly considered Kegel exercises, but surely enough, it gradually shrank and tightened, its shell retracting as fistingless time went by. My vagina is accommodating and resilient.

\section{My vagina is a feminist revolutionary.}

It is not a sacred relic to be kept behind closed doors. It has its own fetishes: social justice, leftist feminism, brown dissent. It is neither feminine nor masculine, but it does not pretend to dwell in a genderless political place. It does not subscribe to recognized categories of desire because it prefers to fashion its own. As it does not mind repetitions, it reimagines them with every positionality. Epistemologically, terms such as "history" or "herstory" baffle it. My vagina hystorically understands its own pain, pleasure, and desires in nuanced strokes of resistance and subversion. 


\section{Kohl 1.2}

16 I am not celebrating my vagina. Rather, I am making public a bodily organ to which mystery, secrecy, and cunningness were wrongly attributed. I am disclosing its mechanisms, its doubts, and its preferences. I am acknowledging the ways in which it hones my practices, sharpens my judgment, and embraces the hystory of my body - and that of my struggle. 